\title{
AWARENESS SYSTEM IMPLEMENTED IN THE EUROPEAN NETWORK
}

\author{
František Janíček ${ }^{*}$ - Martin Jedinák ${ }^{* *}$ - Igor Šulc ${ }^{* * *}$
}

\begin{abstract}
Transmission system in Slovakia is part of a synchronously interconnected system of continental Europe. Besides indisputable technical and economical benefits of cooperation many hazardous factors exist of fault condition spreading with impact on our system. Even today a system break-up escalated into a vast blackout is a real danger. European transmission system operators continually work on preventive measures and develop systems with a goal to handle critical situations. The ambition of the European Awareness System is to signalize the rise of these situations and also assist with system restoration.

K e y w o r d s: transmission system, European Awareness System, system state, real-time operation, area control error
\end{abstract}

\section{INTRODUCTION}

During the power system operation arise a lot of fast changes, which can cause a disproportion between production and consumption of electricity what also means big changes of rotor angles. [1]

The primary target of power system operation is the safety and reliability of the system. Moreover, in electrical power engineering, these terms (security, reliability) are very closely related and cannot be separated. Reliability significantly affects the safety and economy of system operation. Safety is associated with eliminating and minimizing of the failures probability that could lead for example to the threat of human life or another potential danger for the environment. Power system has to comply with the safety and reliability parameters at any time, because it is difficult to imagine such a large system that is safe on the one side and unreliable, or vice versa. [2]

After interconnection of European transmission systems into one system controlled by several operators and endeavour to enhance the security and reliability of electric energy delivery to the final customers, a need to monitor the status of the whole European system in real time arose. One of the consequences of the incident report of the Union for Coordination of the Transmission of Electricity (UCTE) is a recommendation to create an information platform allowing transmission system operators (TSOs) to observe in real-time the actual state of the whole UCTE system in order to quickly react during large disturbances [1]. To fulfil this need and to improve cooperation and coordination of member systems operations, the European Network of Transmission System Operators for Electricity (ENTSO-E) has developed the European
Awareness System (EAS) which provides sharing of selected data [2]. This new system allows, against similar tools, broader coordinated, faster and more efficient reactions to critical situations of individual operators even in greater distances from their own systems.

\section{GENESIS AND MAIN GOALS}

On $18^{\text {th }}$ February 2011, after realizing the necessity of having such a tool for operational planning and analysis of transmission systems, the members of ENTSO-E signed a Memorandum of Understanding regarding the exchange of data in which the TSOs set forth their willingness to actively participate in the data exchange mechanism for the operational TSO business defined as real time and periodical tasks performed for transmission system operational planning, operations and analysis. In 2011 and 2012 , testing of the system by pilot TSOs and evaluation of their experience took place. In the first quarter of 2013, the ENTSO-E Awareness System (EAS) software was completed, and distributed to individual member TSOs throughout the rest of the year. By the end of the year all 41 members of ENTSO-E signed a mutual EAS Data Exchange and Delivery Agreement and were connected to the system. Officially, full operation of EAS is dated on 5th November 2013. Until the end of 2014 implementation of an archive of exchanged data and providing an access to it for all TSOs is anticipated.

EAS ensures instantaneous, ie, real time exchange of relevant information about the operation between individual TSOs that allows them to promptly react in the case of unusual system conditions. Thanks to this system the awareness of all dispatchers of whole pan-European

\footnotetext{
* Institute of Power and Applied Electrical Engineering, Slovak University of Technology, Ilkovičova 3, 81219 Bratislava, frantisek.janicek@stuba.sk; ${ }^{* *}$ Slovenská elektrizačná prenosová sústava, a.s., Obchodná 2, 01008 Žilina, martin.jedinak@sepsas.sk; *** Slovenská elektrizačná prenosová sústava, a.s., Mlynské nivy,59/A 82484 Bratislava, Slovakia
} 


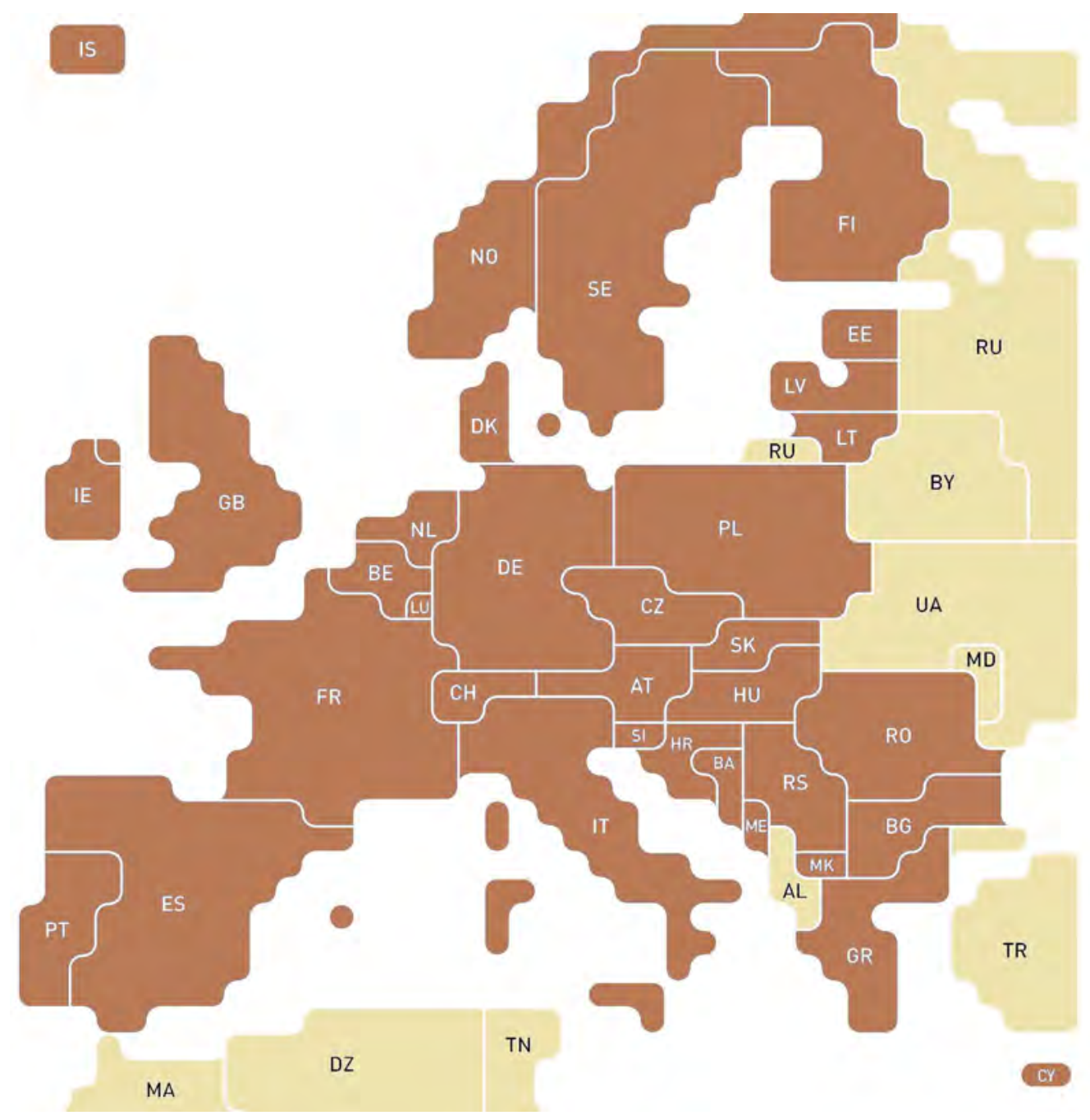

Fig. 1. Member countries of ENTSO-E, [4]

Table 1. Exchanged parameters

\begin{tabular}{|c|c|c|c|}
\hline Data & Unit & Precision & Frequency \\
\hline 1 Frequency & $\mathrm{Hz}$ & $<20 \mathrm{mHz}$ & $\begin{array}{l}\text { Every supervisory control and data } \\
\text { acquisition (SCADA) cycle, and } \\
\text { at worst not more than every } 10 \text { seconds }\end{array}$ \\
\hline 2 Area Control Error (ACE) & & & $\begin{array}{l}\text { According to the cycle of secondary } \\
\text { controllers (SCADA-like measurement cycle), } \\
\text { and at worst not more than every } 10 \text { seconds }\end{array}$ \\
\hline 3 Scheduled total power balance & MW & \multirow{3}{*}{$\begin{array}{l}\text { Positive value } \\
\text { for export, } \\
\text { negative value } \\
\text { for import, seen } \\
\text { from the pTSO } \\
\text { sending the data }\end{array}$} & Every 60 minutes \\
\hline 4 Scheduled power exchanges by border & MW & & Every 60 minutes \\
\hline $\begin{array}{l}5 \text { Real-time total power balance } \\
6 \text { Real-time power exchanges by border }\end{array}$ & $\begin{array}{l}\text { MW } \\
\text { MW }\end{array}$ & & $\begin{array}{l}\text { According to the cycle and the quality of } \\
\text { secondary controllers (SCADA-like } \\
\text { measurement cycle), and at worst } \\
\text { not more than every } 10 \text { seconds }\end{array}$ \\
\hline 7 Generation infeed, if relevant & MW & & Every 5 minutes \\
\hline 8 System state & $\begin{array}{l}0=\text { Normal } \\
1=\text { Alert } \\
2=\text { Emergency } \\
3=\text { Black-out } \\
4=\text { Restoration }\end{array}$ & & On action from the operator \\
\hline 9 Pre-formatted message & $\begin{array}{l}\text { Selection of } \\
\text { value } \\
\text { between } 0 \text { and } 20 \\
\end{array}$ & & On action from the operator \\
\hline
\end{tabular}


transmission system increased and they can immediately react to critical situations in collaboration with partner TSOs by implementing effective remedial actions. EAS is able to provide both types of data, ie, raw and processed real time data to each of the member TSOs by the EAS push-pull system that is sending data and provides access to the database, which allows acquisition and provision of processed and raw real time data to TSOs by both InterControl Center Communications Protocol (ICCP) and a common visualization server. EAS runs as an application on servers located at the so-called hosting entities, which receives online data, processes them and provides them back to individual TSOs. The data are monitored in nine essential parameters and give a complex image about the balance of every transmission system, planned production of electricity, planned and actual power exchange etc.

Altogether, 41 TSOs from 34 countries are members of ENTSO-E, Fig. 1. The ultimate goal of this system is to contribute to the stability of interconnected transmission system and improve the security of electricity delivery to all European inhabitants and to all industrial customers to ensure their connection to a source under any circumstances [3].

\section{EXCHANGED DATA}

Data, which is the subject of exchange by EAS system, are chosen in such a way as to provide a complete overview of the system in question in normal operation and in critical situations. Nine parameters have been chosen as summarized in Tab. 1.

\section{PREDEFINED MESSAGES}

When a non-normal system state is set, it is of utmost interest of other TSOs to have indications of the causes or conditions that lead to it. These indications are given using one or more predefined messages from the following list, Tab. 2.

\section{FREE TEXT MESSAGES}

A special application accessible from a dedicated box on the Control Window opens another window that allows the user to send a free text message with limited characters to any other TSO or sub-group of TSOs by choosing several predefined delivery addresses. The objective is to give precise details of a specific situation ( $\mathrm{eg}$, expected duration of the incident, name of a grid element ... ). The operator can select the target receiver(s): one TSO, all TSOs or a sub-group of TSO (eg, a regional group), but every user can see every information.

Any TSO can send messages to the other TSOs or to specific groups of operators. Each operator can open the message list with the received messages. Messages can be acknowledged or deleted in the message list by using appropriate buttons.
Communication is ensured by an electronic highway. The connection between the electronic highway environment and the hosting sites is the point of delivery of data and of the EAS services by the TSOs as well as ENTSO$\mathrm{E}$, while any failure of the electronic highway environment shall constitute a force majeure event.

\section{PRACTICAL USE OF EAS}

Within the Regional Group of Continental Europe (RG CE), each control area/block is equipped with one secondary controller to minimize the Area Control Error $(\mathrm{ACE})$ in real-time

$$
A C E=P_{\mathrm{m}}-P_{\mathrm{p}}+K_{i}\left(f_{\mathrm{m}}-f_{0}\right) .
$$

Here,

$P_{\mathrm{m}}$ is the sum of the instantaneous measured active power transfers on the tielines,

$P_{\mathrm{p}}$ is the resulting exchange program with all the neighbouring control areas,

$K_{i}$ is the $K$-factor of the control area; a constant $(\mathrm{MW} / \mathrm{Hz})$ set on the secondary controller,

$f_{\mathrm{m}}-f_{0}$ is the difference between the instantaneous measured system frequency and the set-point frequency.

When $\delta f=f_{\mathrm{m}}-f_{0}=0$, under balanced conditions $\left(P_{\mathrm{m}}=P_{\mathrm{p}}\right)$, the area control error will also be equal to zero.

The desired behaviour of the secondary controller over time will be obtained by assigning a proportional-integral characteristic to control circuits, in accordance with the following equation

$$
\Delta P_{i}=-\beta_{i} A C E_{i}-\frac{1}{T_{i}} \int A C E_{i} \mathrm{~d} t
$$

Here,

$\Delta P_{i}$ i is the correcting variable of the secondary controller governing control generators in $i$-th control area,

$\beta_{i}$ is the proportional factor (gain) of the secondary controller in $i$-th control area,

$T_{i}$ is the integration time constant of the secondary controller in $i$-th control area [5].

Each TSO is responsible for the quality of power and frequency control within the respective control area.

On 28 ${ }^{\text {th }}$ October 2013 (between 17:37 and 17:47), a temporary large frequency deviation of up to $130 \mathrm{mHz}$ occurred in the Regional Group of Continental Europe during strong wind conditions in northern Europe. The EAS real-time awareness showed this on the "Frequency" map (the first level of $-100 \mathrm{mHz}$ deviation was reached) and on "System State" and "Imbalance" maps it displayed the main cause and location: Normal operation but highly imbalanced situation inside Germany (more 


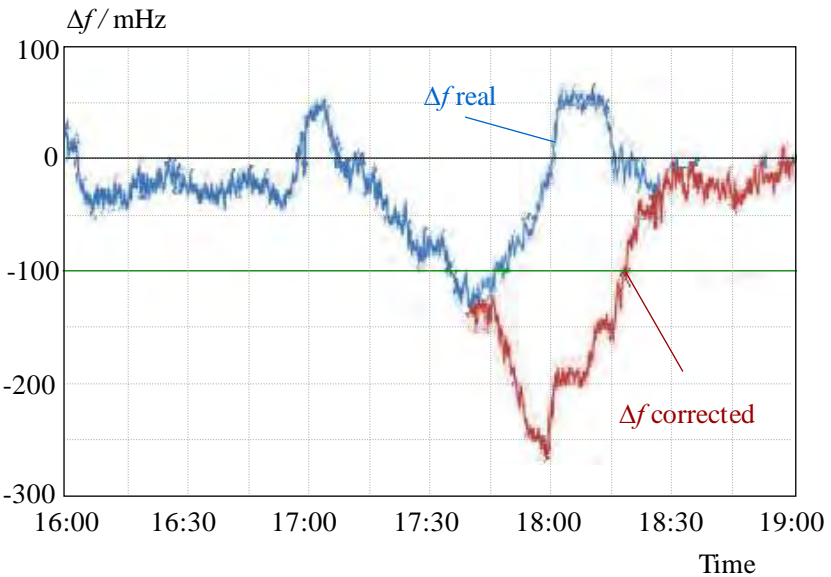

Fig. 2. Frequency in the control area of France

Table 2. List of predefined messages

\begin{tabular}{|c|c|c|}
\hline Item & \# & $\begin{array}{l}\text { Cause leading to the } \\
\text { particular system state }\end{array}$ \\
\hline General & 01 & Outage of important element \\
\hline \multirow[t]{2}{*}{ Flows } & 02 & Relevant N-1 rule criterion violation \\
\hline & 03 & $\begin{array}{l}\text { Flows beyond transmission } \\
\text { limits (overloading) }\end{array}$ \\
\hline \multirow[t]{5}{*}{ Balance } & 04 & $\begin{array}{l}\text { Loss of significant amount } \\
\text { of generation / Unexpected } \\
\text { high demand of energy }\end{array}$ \\
\hline & 05 & $\begin{array}{l}\text { Unexpected high infeed } \\
\text { of energy / Loss of significant } \\
\text { amount of consumption }\end{array}$ \\
\hline & 06 & Margin below required minimum \\
\hline & 07 & $\begin{array}{l}\text { Imbalanced system with } \\
\text { no margin available }\end{array}$ \\
\hline & 08 & Actions for energy savings \\
\hline \multirow[t]{2}{*}{$\begin{array}{l}\text { Load } \\
\text { shedding }\end{array}$} & 09 & Manual load shedding \\
\hline & 10 & Automatic load shedding \\
\hline \multirow[t]{2}{*}{$\begin{array}{l}\text { Frequency } \\
\text { deviation }\end{array}$} & 11 & $\begin{array}{l}\text { Frequency deviation } \\
\text { higher than } 200 \mathrm{mHz}\end{array}$ \\
\hline & 12 & Frequency deviation higher than $1 \mathrm{~Hz}$ \\
\hline \multirow[t]{2}{*}{ LFC status } & 13 & LFC frozen mode \\
\hline & 14 & LFC frequency mode \\
\hline \multirow[t]{2}{*}{ Grid } & 15 & Partial islanding within a control area \\
\hline & 16 & Large (cross-border) splitting \\
\hline \multirow[t]{3}{*}{$\mathrm{NCC}$} & 17 & Security analysis unavailable \\
\hline & 18 & $\begin{array}{l}\text { SCADA (principal and back-up) } \\
\text { not available }\end{array}$ \\
\hline & 19 & $\begin{array}{l}\text { National Control Center } \\
\text { out of operation }\end{array}$ \\
\hline Other & 20 & $\begin{array}{l}\text { Critical event (weather / } \\
\text { disaster / terrorism attack }\end{array}$ \\
\hline
\end{tabular}

than $-750 \mathrm{MW}$. TSOs noticed this extraordinary situation via EAS.

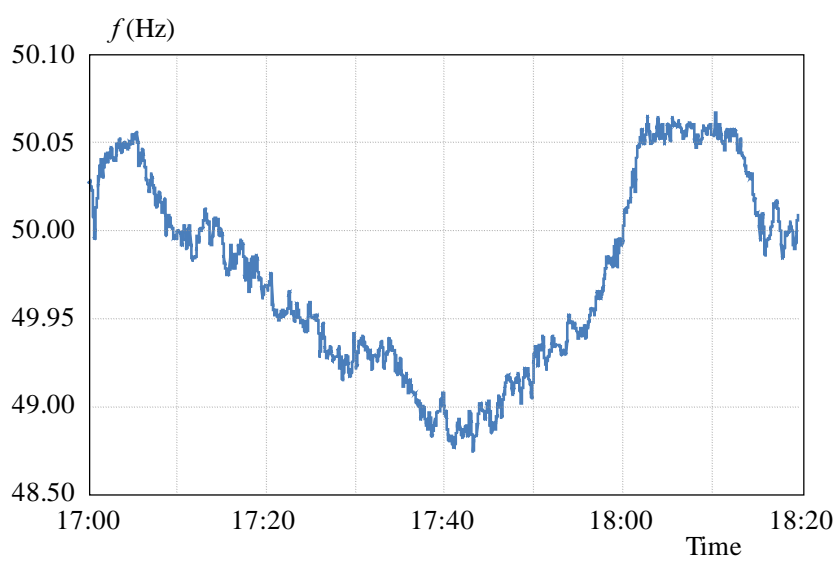

Fig. 3. Frequency in the system of TenneT Germany

In real time, to fill the gap and straighten the system frequency, RTE (TSO France) adjusted its production by $2500 \mathrm{MW}$. Without the reaction of RTE within the interconnected system the frequency would have dropped down below the limit of $250 \mathrm{mHz}$ that would have caused the National Defence plans to be activated with a questionable reaction of power sources. Corrected and real frequency curves in the Control area France during this extraordinary situation are shown in Fig. 2.

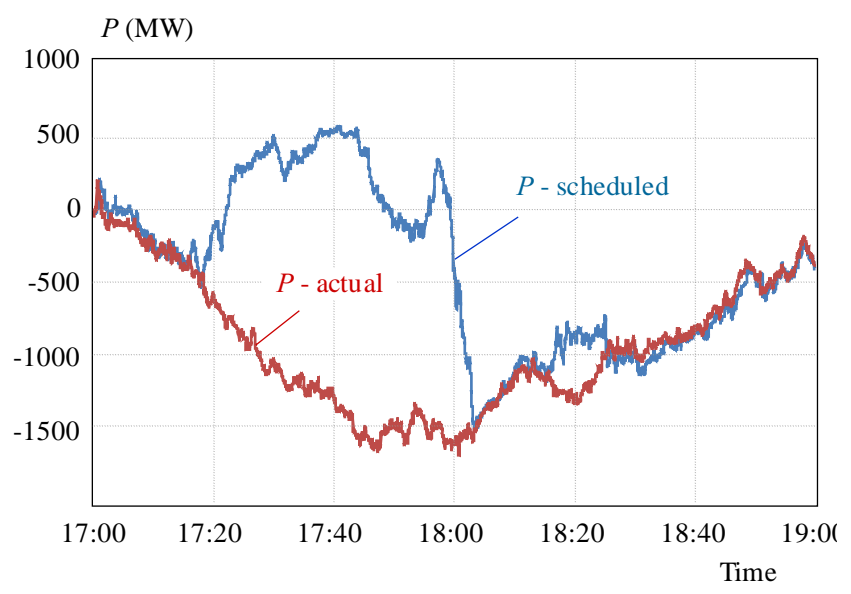

Fig. 4. Imbalance in the control area of TenneT Germany

In Germany, TenneT it is one of the four transmission system operators operating through its subsidiary TenneT TSO GmbH. Real system frequency in the control area TenneT German is presented in Fig. 3.

Finally, Fig. 4 displays the power imbalance in the control area of TenneT Germany.

EAS was not used as expected, as it should have been. There were no messages or system state change in Germany. The added value of the tool appeared too late for RTE operators. 


\section{EAS IN SOLVING OF CRITICAL SITUATIONS}

Emergency operation and all important actions within the synchronous system are covered by the Operation Handbook, Policy 5: Emergency Operations [6]. EAS could be most useful in restoration of the transmission system because the information acquired from individual TSOs, thus the current frequency and power balance of the area, is crucial for determining the frequency and resynchronization leader. Actuality and reliability are the key properties of information in the state of restoration. Availability of all the information for all TSOs from a single system without the need of informing all partners individually is also of high value.

The frequency leader shall announce its nomination and resignation to all RG CE TSOs using EAS. Prior to reconnection, one frequency leader is selected for the rest of the system recovery. This frequency leader shall announce its position to all RG CE TSOs using EAS (precising resignation of the other frequency leader). If the secondary controllers of both frequency leaders were previously in the Frequency Control Mode, one of the two frequency leaders has to switch its secondary control to the Frozen Mode to avoid staying with two secondary controllers in the Frequency Control Mode.

\section{CONCLUSION}

Mutual real time data exchange is inevitable to ensure reliable operation of the interconnected ENTSO-E system. EAS as a tool for monitoring and sharing operational information of individual TSOs is becoming an essential element of control systems and critical situation scenarios. However, its practical use does not reach the potential possibilities which it was designed for. Determination and definition of conditions of use and decision making rules for dispatchers should be integrated into a collective document approved by ENTSO-E and also into operational documentation or the Operation Handbook.

\section{REFERENCES}

[1] Cintula, B.-ELESChOVÁ, Ž.—BELÁŇ, A.—LIŠKA, M. : Transient Stability of Synchronous Generator for Selected Events, Proceedings of the 12th WSEAS International Conference on Electric Power Systems, High Voltages, Electric Machines (POWER '12) 12 (2012), 47- 52, Prague.
[2] Cintula, B.-VIGlaš, D.-BeniugA, C.-R.: Power System Security Operation in Applying The N-1 Criterion, ELITECH12 - 14th Conference of Doctoral Students 14 (2012), 16 , Bratislava.

[3] Final Report - System Disturbance on 4 November 2006, https://www.entsoe.eu/fileadmin/user_upload/_library/ publications/ce/otherreports/Final-Report-20070130.pdf.

[4] ENTSO-E launches tendering process on European Awareness System, https://www.entsoe.eu/news-events/announcements/ announcements-archive/Pages/News/entso-e-launchestendering-process-on-european-awareness-system-.aspx.

[5] ENTSO-E Members Launch the European Awareness System to Help Keep Europe Switched On, https://www.entsoe.eu/ news-events/announcements/announcements-archive/Pages/ News/entso-e-members-launch-the-european-awarenesssystem-to-help-keep-europe-switched-on.aspx.

[6] ENTSO-E Member Companies, https://www.entsoe.eu/aboutentso-e/inside-entso-e/member-companies/Pages/default.aspx.

[7] RG CE Operation Handbook, Appendix 1: Load-Frequency Control and Performance, UCTE, 2004, https://www.entsoe.eu/ fileadmin/user_upload/_library/publications/entsoe/Operation _Handbook/Policy_1_Appendix\%20_final.pdf.

[8] RG CE Operation Handbook, Policy 5: Emergency Operations, ENTSO-E, 2010, available on https://www.entsoe.eu/ fileadmin/user_upload/_library/publications/entsoe/ Operation_Handbook/Policy_5_final.pdf.

Received 15 March 2014

František Janíček (prof, Ing, PhD), born in 1954, graduated from the Faculty of Electrical Engineering of the Slovak University of Technology in 1979 and received his PhD degree in electrical power engineering in 1984. Since 1999 he has been full professor, currently Head of the Institute of Power and Applied Electrical Engineering of the Slovak University of Technology. He has authored or co-authored university textbooks and lecture books, four scientific monographs, more than 50 articles in periodicals, and more than 180 lectures at scientific conferences. Professor Janíček is a member of the Slovak Board of the World Energy Congress, statutory officer of the EE Association and member of the Committee on Energy Research and Technology of the International Energy Agency.

Martin Jedinák (Ing), born in 1983, graduated from the Faculty of Electrical Engineering and Information Technology of the Slovak University of Technology in 2008. Currently he works as an analyst at the System Operation Planning Department of the Slovak Electricity Transmission System, joint stock company (Slovenská elektrizačná prenosová sústava, a.s.). His research activities are focused on system security, network analysis and related remedial actions.

Igor Šulc (Ing), born in 1983, graduated from the Faculty of Electrical Engineering and Information Technology of the Slovak University of Technology in 2008. Currently he works at Trade Department of the Slovak Transmission System, joint stock company (Slovenská elektrizačná prenosová sústava, a.s.). His research activities are focused on ancillary services and losses in transmission system. 